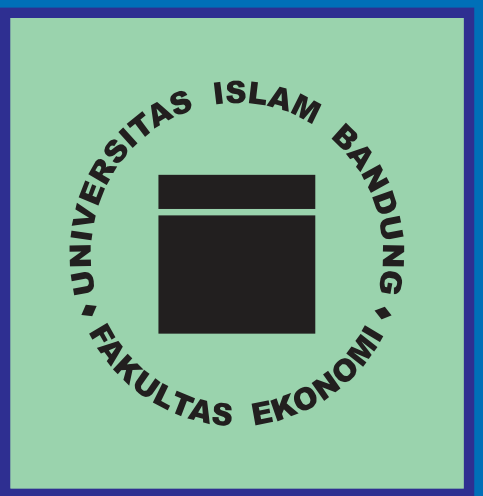

Vol.21 No.2

September 2020

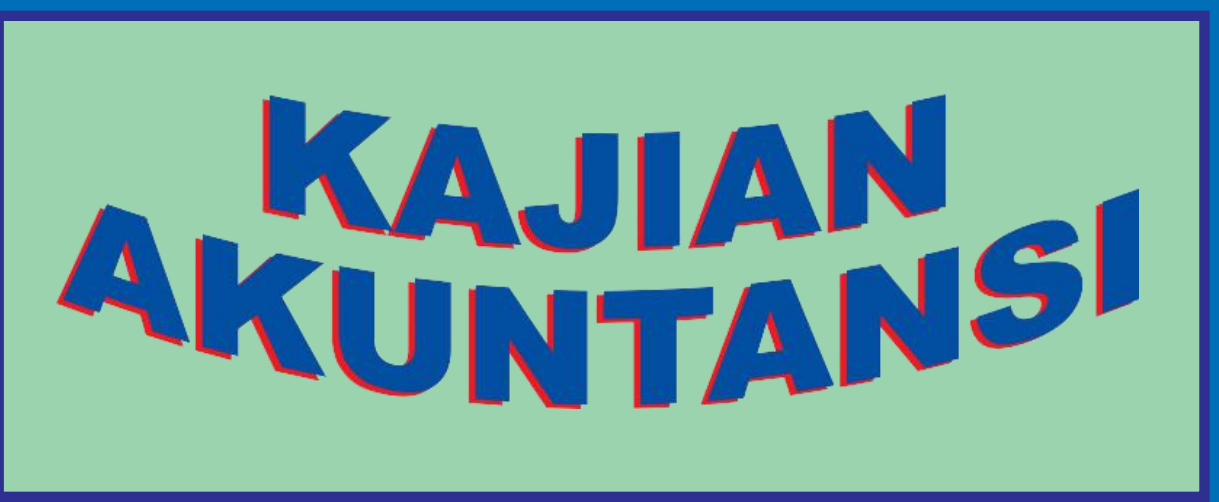

ISSN : 1693 - 0614 e-ISSN : 2581 - 074X
Deliana, Abdul Rahman

Ilham Hidayah Napitupulu, Anggiat Situngkir,

Chairunnisa Arfanni

Edi Sukarmanto, Magnaz Lestira Oktaroza, Karina Nur Astari

Eka Nurmala Sari, Muhyarsyah, Nunung Sri Wahyuni

Nurhayati, Muhammad Kevin Aprilio

Uli Wildan Nuryanto, Masyhudzulhak

Djamil MZ, Achmad Hidayat Sutawidjaya, Ahmad Badawi Saluy.

Riyang Mardini

Annisa Nadiyah

Rahmani

Diamonalisa Sofianty, Lena Herlina.
Efektivitas Audit Internal Pada Perguruan Tinggi Negeri Di Provinsi Sumatera Utara.

Pengaruh Transfer Pricing Dan Profitabilitas Terhadap Tax Avoidance.

Related Party Transaction Memperkuat Pengaruh Political Connection Terhadap Audit Delay?

Pengaruh Sistem Pengendalian Intern Pemerintah Dan Ketersediaan Anggaran Terhadap Efektivitas Penerapan Sistem Informasi Keuangan Daerah Pada Pemerintah Provinsi Dan Kabupaten/Kota Se-Sumatera Utara.

Pengaruh Rasio Solvabilitas Terhadap Kondisi Financial Distress

Implikasi Keunggulan Bersaing Terhadap Kinerja Organisasi Pada Sektor Industri Manufaktur Kimia di Provinsi Banten

Pengaruh Kinerja ICSR Terhadap Readability ICSR Menggunakan Gunning Fog Dan Flesch-Kincaid Indeks Dengan Size, Kinerja Keuangan, Leverage Dan Growth Sebagai Variabel Kontrol.

Dampak Covid-19 Terhadap Harga Saham Dan Kinerja Keuangan Perusahaan

Pengaruh Pengungkapan Corporate Social Responsibility Dan Mekanisme Good Corporate Governance Terhadap Tax Avoidance

Diterbitkan oleh :

ISSN

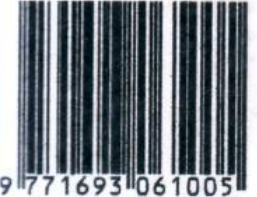

( P 2 U )

Pusat Penerbitan Universitas 


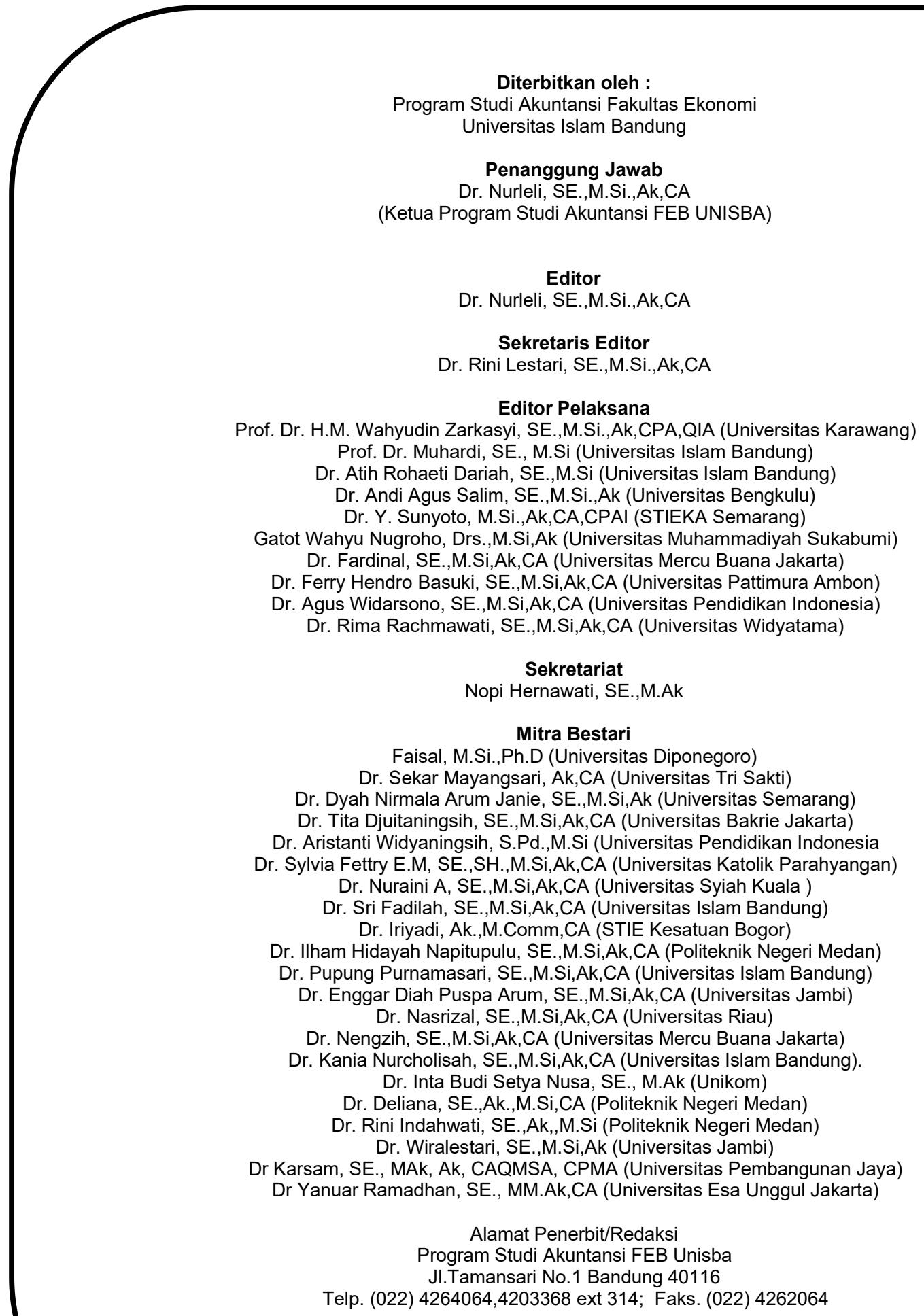

Terbit dua kali dalam setahun : Maret dan September Terbit pertama kali Maret 2003

Redaksi menerima naskah berupa artikel penelitian maupun artikel hasil pengkajian. Pendapat yang dimuat dalam jurnal ini sepenuhnya pendapat pribadi penulis ,

tidak mencerminkan pendapat redaksi,

dan telah disajikan menurut sistematika yang ditetapkan pada halaman akhir jurnal ini . 


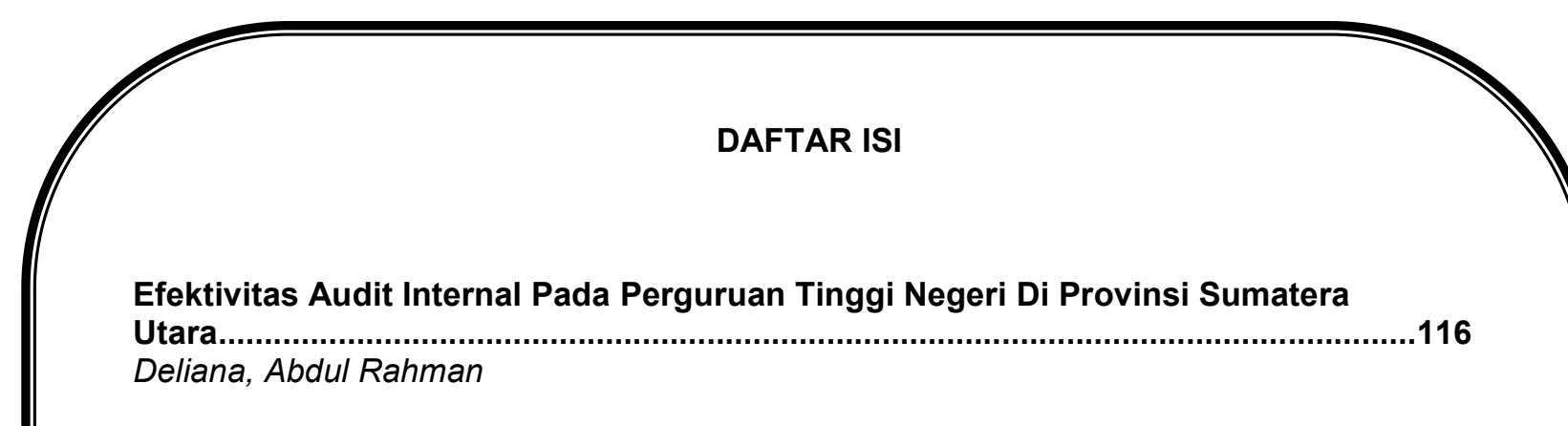

Pengaruh Transfer Pricing Dan Profitabilitas Terhadap Tax Avoidance .126

Ilham Hidayah Napitupulu, Anggiat Situngkir, Chairunnisa Arfanni

Related Party Transaction Memperkuat Pengaruh Political Connection

Terhadap Audit Delay?

Edi Sukarmanto, Magnaz Lestira Oktaroza, Karina Nur Astari

Pengaruh Sistem Pengendalian Intern Pemerintah Dan Ketersediaan Anggaran Terhadap Efektivitas Penerapan Sistem Informasi Keuangan Daerah Pada Pemerintah Provinsi Dan Kabupaten/Kota Se-Sumatera Utara.

Eka Nurmala Sari, Muhyarsyah, Nunung Sri Wahyuni

Pengaruh Rasio Solvabilitas Terhadap Kondisi Financial Distress Nurhayati, Muhammad Kevin Aprilio

Implikasi Keunggulan Bersaing Terhadap Kinerja Organisasi Pada Sektor Industri Manufaktur Kimia di Provinsi Banten.

Uli Wildan Nuryanto, Masyhudzulhak Djamil MZ, Achmad Hidayat Sutawidjaya,

Ahmad Badawi Saluy

Pengaruh Kinerja ICSR Terhadap Readability ICSR Menggunakan Gunning Fog Dan Flesch-Kincaid Indeks Dengan Size, Kinerja Keuangan, Leverage Dan Growth Sebagai Variabel Kontrol

Riyang Mardini

Dampak Covid-19 Terhadap Harga Saham Dan Kinerja Keuangan Perusahaan. Annisa Nadiyah Rahmani.

Pengaruh Pengungkapan Corporate Social Responsibility Dan Mekanisme Good Corporate Governance Terhadap Tax Avoidance.

Diamonalisa Sofianty, Lena Herlina I 


\title{
PENGARUH TRANSFER PRICING DAN PROFITABILITAS \\ TERHADAP TAX AVOIDANCE
}

\author{
Ilham Hidayah Napitupulu \\ Politeknik Negeri Medan \\ Ilhamhasan77@yahoo.com
}

\author{
Anggiat Situngkir \\ Politeknik Negeri Medan
}

\author{
Chairunnisa Arfani \\ Politeknik Negeri Medan
}

\begin{abstract}
Tax avoidance is one of the taxpayers' efforts to reduce the amount of tax payable legally by using loopholes contained in tax regulations. This study aims to examine the effect of transfer pricing and profitability (ROA) on tax avoidance. This study is tested on seven companies from nineteen plantation companies listed on IDX in 2013-2019 which are selected by purposive sampling method. The analysis technique used in this research is multiple linear regression analysis. The findings show that transfer pricing and profitability have no effect on tax avoidance.
\end{abstract}

\section{Keywords : Tax Avoidance, Transfer Pricing, Profitability.}

\begin{abstract}
Abstrak
Penghindaran pajak merupakan salah satu upaya wajib pajak untuk mengurangi jumlah pajak terutang secara legal dengan menggunakan celah yang terdapat dalam peraturan perpajakan. Penelitian ini bertujuan untuk menguji pengaruh transfer pricing dan profitabilitas (ROA) terhadap tax avoidance. Penelitian ini diujikan pada tujuh perusahaan dari sembilan belas perusahaan perkebunan yang terdaftar di BEI tahun 20132019 yang dipilih dengan metode purposive sampling. Teknik analisis yang digunakan dalam penelitian ini adalah analisis regresi linear berganda. Hasil analisis menunjukkan bahwa transfer pricing dan profitabilitas tidak berpengaruh pada tax avoidance.
\end{abstract}

\section{Kata Kunci: Tax Avoidance,Transfer Pricing, Profitabilitas.}

\section{PENDAHULUAN}

Tax avoidance merupakan salah satu cara untuk menghindari pajak secara legal yang tidak melanggar peraturan perpajakan. Penghindaran pajak dianggap rumit karena di satu sisi diperbolehkan, namun di sisi lain tidak diinginkan (Maharani dan Suardana, 2014). Penghindaran pajak yang dilakukan perusahaan bukan merupakan suatu kebetulan namun merupakan hasil kebijakan perusahaan (Hanafi dan Harto, 2014). 
Penghindaran pajak sering dilakukan oleh perusahaan multinasional melalui penerapan transfer pricing. Transfer pricing adalah suatu harga jual khusus yang ditetapkan dalam pertukaran antar divisional untuk mencatat pendapatan divisi penjual (selling division) dan biaya dari divisi pembeli (buying division) (Hansen dan Mowen, 2007). Transfer pricing merupakan salah satu cara perusahaan untuk menghemat pengeluaran pajaknya. Namun, Transfer pricing sering sekali disalahgunakan oleh perusahaan sebagai alat penghindaran pajak (Nugraha dan Kristanto, 2019). Salah satunya yaitu PT Toyota Motor Manufacturing Indonesia (PT TMMIN) yang diduga melakukan transfer pricing. Perusahaan ini menjual mobilnya kepada anak perusahaan di Singapura dengan harga yang lebih rendah dari Cost of Good Sold (COGS) sehingga harus menanggung kerugian atas penjualan tersebut. Namun kerugian tersebut ditutupi dengan keuntungan dari penjualan di Indonesia dengan harga yang lebih tinggi dari COGS. Hal ini menyebabkan PT TMMIN memiliki laba yang menurun meskipun omzet produksi dan penjualannya meningkat yang pada akhirnya menyebabkan pajak yang dibayar rendah (Sugiharto, 2014). Penelitian yang dilakukan Lutfia dan Pratomo (2018), Citra dan Harto (2019), Sentanu et al (2016), Taylor dan Richardson (2012), Lingga (2012), dan Wilmott (2010) menunjukkan bahwa transfer pricing memiliki pengaruh yang signifikan terhadap tax avoidance sedangkan penelitian yang dilakukan oleh Falbo dan Firmansyah (2018) dan Panjalusman et al (2018) menyatakan bahwa transfer pricing tidak memiliki pengaruh terhadap tax avoidance.

Penghindaran pajak juga dilakukan oleh perusahaan yang memiliki Return on Assets (ROA) yang tinggi. ROA yang tinggi mencerminkan laba perusahaan yang juga tinggi. Apabila rasio profitabilitas tinggi, berarti menunjukkan adanya efisiensi yang dilakukan oleh pihak manajemen untuk menghasilkan laba tinggi (Noor dan Sabli, 2012). Laba harus dikenakan pajak sesuai dengan peraturan yang berlaku. Semakin tinggi labanya, maka beban pajak yang harus ditanggung juga akan semakin tinggi. Hal ini memicu perusahaan untuk melakukan penghindaran pajak, karena beban pajak yang tinggi tersebut akan mengurangi penghasilan perusahaan. Penelitian yang dilakukan oleh Noor dan Sabli (2012) menunjukkan bahwa profitabilitas berpengaruh terhadap tax avoidance yang diproksikan dengan Cash Effective Tax Rate (CETR). Laba yang besar akan meningkatkan jumlah pajak penghasilan karena laba yang dihasilkan oleh perusahaan merupakan dasar pengenaan pajak penghasilan sehingga perusahaan akan 
berusaha untuk menghindari kenaikan jumlah beban pajak dengan melakukan tindakan tax avoidance. Penelitian ini sejalan dengan yang dilakukan oleh Putriningsih et al (2018), Andhari dan Sukartha (2017), Dewinta dan Setiawan (2016), dan Darmawan dan Sukartha (2014). Penelitian ini berbanding terbalik dengan penelitian yang dilakukan oleh Cahyono et al (2016), Nursari et al (2017), Permata et al (2018) dan Wahyuni et al (2019) yang menyatakan bahwa profitabilitas tidak berpengaruh terhadap tax avoidance.

Berdasarkan uraian di atas, masih terdapat keraguan mengenai hubungan transfer pricing dan profitabilitas terhadap tax avoidance yang disebabkan karena adanya perbedaan hasil penelitian. Oleh karena itu, penelitian ini dilakukan kembali untuk menguji sejauh mana hubungan antar variabel yang ada. Penelitian ini dilakukan pada perusahaan perkebunan yang terdaftar di Bursa Efek Indonesia periode 2013-2019, maka dipilih topik dengan judul "Pengaruh Transfer Pricing dan Profitabilitas Terhadap Tax Avoidance".

\section{LANDASAN TEORI DAN PENGEMBANGAN HIPOTESIS}

\subsection{Tax Avoidance}

Tax avoidance adalah salah satu cara yang digunakan perusahaan untuk menghindari pajak secara legal yang tidak melanggar peraturan perpajakan (Maharani dan Suardana, 2014). Sementara menurut Pohan (2013) Tax avoidance adalah upaya yang dilakukan wajib pajak untuk menghindari pajak secara legal karena tidak bertentangan dengan peraturan perpajakan yang ada dengan memanfaatkan kelemahan (grey area) yang ada di dalam undang-undang dan peraturan perpajakan untuk memperkecil jumlah pajak terutang. Dengan demikian, dapat disimpulkan bahwa tax avoidance merupakan upaya untuk menghindari pajak oleh wajib pajak tanpa melanggar ketentuan pajak yang berlaku dengan pemanfaatan kelemahan yang ada dalam peraturan pajak tersebut.

Model estimasi pengukuran tax avoidance yang digunakan dalam penelitian ini adalah model Cash Effective Tax Rate (CETR). Pengukuran ini digunakan karena dapat menjelaskan adanya kegiatan penghindaran pajak dengan baik. Semakin tinggi persentase CETR yang dekat dengan tarif pajak badan sebesar 25\% menunjukkan bahwa semakin rendah tingkat penghindaran pajak perusahaan tersebut (Kurniasih dan Sari, 2013).

Adapun peneliti-peneliti terdahulu yang menggunakan CETR sebagai pengukuran tax avoidance adalah Praditasari dan Setiawan (2017), Maharani dan 
Suardana (2014), Annisa et al (2017), Jafri dan Mustikasari (2018). Tax avoidance dirumuskan sebagai berikut :

$$
\mathrm{CETR}=\frac{\text { Beban Pajak }}{\text { Laba Sebelum Pajak }}
$$

\subsection{Transfer Pricing}

Transfer pricing adalah suatu harga yang dibebankan ketika satu bagian di perusahaan menyediakan barang atau jasa ke bagian lain dari perusahaan yang sama (Garrison et al, 2009). Namun, istilah transfer pricing ini sering sekali dikonotasikan sebagai suatu hal yang tidak baik (abuse of transfer pricing), yaitu pengalihan penghasilan dari perusahaan di negara dengan tarif pajak yang tinggi ke perusahaan lain dalam satu grup di negara dengan tarif pajak yang lebih rendah sehingga mengurangi total beban pajak perusahaan tersebut (Setiawan, 2014). Pada sisi pemerintahan, transfer pricing diyakini mengakibatkan berkurang atau bahkan hilangnya potensi penerimaan pajak suatu negara dikarenakan pengalihan penghasilan tersebut.

Desai et al (2006) menekankan bahwa transaksi antara pihak relasi yang terletak di lokasi yuridiksi pajak yang bervariasi menawarkan peluang besar untuk terlibat dalam penghindaran pajak. Perusahaan multinasional dapat melakukan transfer pricing untuk menghindari pajak melalui transaksi pihak relasi tersebut. Terdapat tiga metode penentuan harga transfer menurut Kaplan dan Atkinson (1998) yaitu :

1. Market-based transfer pricing yaitu suatu penentuan harga transfer yang menggunakan harga pasar sebagai dasar harga transfer. Harga pasar tersebut merupakan harga yang ditetapkan oleh mekanisme permintaan dan penawaran pasar.

2. Cost-based transfer pricing yaitu suatu penentuan harga transfer yang menggunakan perhitungan biaya yang dikeluarkan untuk menghasilkan suatu produk sebagai dasar harga transfer.

3. Negotiated transfer pricing yaitu suatu penentuan harga transfer berdasarkan negosiasi antar pihak yang berkepentingan. Dalam hal ini, informasi tentang harga pasar dan biaya dapat digunakan sebagai pertimbangan dalam negosiasi. 
Dalam penelitian ini, transfer pricing diukur dari piutang usaha pihak yang memiliki hubungan istimewa dibagi dengan total piutang perusahaan. Adapun peneliti terdahulu yang menggunakan rumusan ini adalah Margaretha dan Jenni (2019) dan Panjalusman et al (2018). Transfer pricing dirumuskan sebagai berikut:

$$
\mathrm{TP}=\frac{\text { Piutang usaha pihak yang memiliki hubungan istimewa }}{\text { Total Piutang }}
$$

Transfer pricing menurut Nurhayati (2013) adalah suatu mekanisme penetapan harga yang tidak wajar atas transaksi penyerahan barang atau jasa oleh pihak-pihak yang memiliki hubungan istimewa (related parties). Mekanisme tersebut dapat dilakukan dengan cara menaikkan harga (mark up) atau menurunkan harga (mark down) yang kebanyakan dilakukan oleh perusahaan global (multinational enterprise) (Suryana, 2012). Hal ini bisa mendorong dilakukannya praktik transfer pricing yang digunakan untuk menghindari pajak. Perusahaan multinasional dapat memanfaatkan celah yang ada di peraturan perpajakan (grey area) untuk merencanakan pajak dengan melakukan transfer pricing dengan cara memindahkan keuntungan yang diperoleh perusahaan ke perusahaan lain yang masih dalam satu grup di negara lain dengan tujuan agar total beban pajak yang harus ditanggung perusahaan menjadi rendah (Mangoting, 2000).

Penelitian yang dilakukan oleh Lutfia dan Pratomo (2018), Sentanu et al (2016), Taylor dan Richardson (2012), Lingga (2012) dan Wilmott (2010) menyatakan bahwa transfer pricing berpengaruh terhadap terjadinya penghindaran pajak (tax avoidance).

H1. Transfer pricing berpengaruh terhadap tax avoidance

\subsection{Profitabilitas}

Menurut Kasmir (2014) rasio profitabilitas adalah rasio yang digunakan untuk menggambarkan kemampuan perusahaan dalam mendapatkan laba atau keuntungan. Sartono (2010) berpendapat bahwa profitabilitas merupakan rasio yang digunakan untuk mengukur kemampuan perusahaan dalam menghasilkan laba dalam hubungannya dengan penjualan, total aktiva maupun modal sendiri. Penelitian ini menggunakan Return on Asset (ROA) sebagai indikator profitabilitas karea ROA dapat menggambarkan kemampuan perusahaan dalam pengelolaan aset yang ada secara efektif dan efisien untuk menghasilkan laba perusahaan. Semakin tinggi rasio ini, maka menandakan semakin baik performa perusahaan menghasilkan laba melalui penggunaan aset yang ada di dalam perusahaan (Darmawan dan Sukartha, 2014). 
Adapun penelitian terdahulu yang menggunakan ROA sebagai proksi profitabilitas adalah Kurniasih dan Sari (2013), Cahyono et al (2016), Subagiastra et al (2016), Praditasari dan Setiawan (2017) dan Napitupulu et al (2019). Profitabilitas dirumuskan sebagai berikut :

$$
\mathrm{ROA}=\frac{\text { Laba Setelah Pajak }}{\text { Total Aset }}
$$

Perusahaan dengan nilai ROA yang tinggi menunjukkan perusahaan tersebut memiliki laba yang tinggi (Kurniasih \& Sari, 2013). Hal ini menunjukkan bahwa manajemen mampu mengelola aset perusahaan secara efektif. Perusahaan yang memiliki ROA negatif menandakan perusahaan tersebut mengalami kerugian yang juga berarti bahwa manajemen kurang mampu untuk mengelola seluruh aset yang ada di perusahaan (Maharani \& Suardana, 2014). Indikator ROA adalah laba bersih setelah pajak dibandingkan dengan total aset yang digunakan oleh perusahaan dalam menjalankan operasi perusahaan. Laba yang besar akan meningkatkan beban pajak yang harus dibayar karena laba yang dihasilkan oleh perusahaan merupakan dasar pengenaan pajak sehingga perusahaan akan berusaha untuk menghindari kenaikan jumlah beban pajak dengan melakukan tindakan tax avoidance. Pernyataan tersebut didukung oleh penelitian yang dilakukan Putriningsih et al (2018), Andhari dan Sukartha (2017), Dewinta dan Setiawan (2016), dan Darmawan dan Sukartha (2014) yang menyatakan return on assets memiliki pengaruh terhadap tax avoidance.

H2. Return on assets berpengaruh terhadap tax avoidance

\section{METODOLOGI PENELITIAN}

Penelitian ini menggunakan metode penelitian kuantitatif karena data yang digunakan berupa data kuantitatif laporan keuangan perusahaan yang diambil dari website Bursa Efek Indonesia. Penelitian ini menggunakan pendekatan kuantitatif, maka alat analisis utama yang digunakan untuk menguji pengaruh antara variabel-variabel yang diteliti dan membuat kesimpulan berdasarkan hasil perhitungan yaitu menggunakan statistik.Populasi penelitian ini adalah perusahaan perkebunan yang terdaftar di Bursa Efek Indonesia selama periode 2013-2019 sebanyak 19 perusahaan. Penentuan sampel dilakukan dengan menggunakan metode purposive sampling dengan beberapa kriteria yang sudah ditetapkan dan didapatkan sebanyak 7 perusahaan sebagai sampel dalam penelitian ini. Penelitian ini menggunakan metode analisis regresi linear berganda. 


$$
\mathrm{Y}=\alpha+\beta 1 . \mathrm{TP}+\boldsymbol{\alpha} 2 . \mathbf{R O A}+\varepsilon
$$

\section{HASIL DAN DISKUSI}

Penelitian ini menemukan bahwa transfer pricing dan return on asset tidak berpengaruh terhadap tax avoidance. Hasil uji statistik dapat dilihat pada tabel 1.

\section{Tabel 1}

\section{Hasil Uji Statistik}

\begin{tabular}{lccccc}
\hline Variabel & R Square & B Value & $\begin{array}{l}\text { Signification } \\
\text { Value }\end{array}$ & $\begin{array}{l}\text { Signification } \\
\text { Standard } \\
\text { (alpha) }\end{array}$ & Keputusan \\
& & & & 0,05 & Tidak \\
\hline $\begin{array}{l}\text { Transfer Pricing } \rightarrow \text { Tax } \\
\text { Avoidance }\end{array}$ & 0,041 & $-0,008$ & 0,772 & & Berpengaruh \\
ROA $\rightarrow$ Tax Avoidance & & $-0,278$ & 0,247 & 0,05 & Tidak \\
& & & & & Berpengaruh \\
\hline
\end{tabular}

Variabel rasio transfer pricing (X1) memiliki nilai signifikan sebesar 0,772 yang berarti lebih besar dari 0,05 maka dapat disimpulkan bahwa rasio transfer pricing (X1) tidak berpengaruh secara parsial terhadap tax avoidance (Y). Interpretasi dari persamaan regresi tersebut dapat dilihat dari nilai koefisien TF sebesar -0,008 yang menyatakan bahwa jika transfer pricing mengalami peningkatan satu satuan maka akan meningkatkan tax avoidance sebesar -0,008. Sebaliknya apabila transfer pricing mengalami penurunan satu satuan maka tax avoidance akan mengalami penurunan juga sebesar -0,008.

Variabel rasio return on asset (X2) memiliki nilai signifikan sebesar 0,247 yang berarti lebih besar dari 0,05 maka dapat disimpulkan bahwa rasio return on asset (X2) tidak berpengaruh secara parsial terhadap tax avoidance (Y). Interpretasi dari persamaan regresi tersebut dapat dilihat dari nilai koefisien ROA sebesar -0,278 yang menyatakan bahwa jika return on asset mengalami peningkatan satu satuan maka akan meningkatkan tax avoidance sebesar -0,278. Sebaliknya apabila return on asset mengalami penurunan satu satuan maka tax avoidance akan mengalami penurunan juga sebesar -0,278.

\subsection{Pengaruh Transfer Pricing Terhadap Tax Avoidance}

Transfer pricing menurut Nurhayati (2013) adalah suatu mekanisme penetapan harga yang tidak wajar atas transaksi penyerahan barang atau jasa oleh pihak-pihak yang 
memiliki hubungan istimewa (related parties). Mekanisme tersebut dapat dilakukan dengan cara menaikkan harga (mark up) atau menurunkan harga (mark down) yang kebanyakan dilakukan oleh perusahaan global (multinational enterprise) (Suryana, 2012). Hal ini bisa mendorong dilakukannya praktik transfer pricing yang digunakan untuk menghindari pajak. Perusahaan multinasional dapat memanfaatkan celah yang ada di peraturan perpajakan (grey area) untuk merencanakan pajak dengan melakukan transfer pricing dengan cara memindahkan keuntungan yang diperoleh perusahaan ke perusahaan lain yang masih dalam satu grup di negara lain dengan tujuan agar total beban pajak yang harus ditanggung perusahaan menjadi rendah (Mangoting, 2000).

Hasil penelitian ini menunjukkan bahwa transfer pricing tidak memiliki pengaruh terhadap tax avoidance. Nilai rata-rata transfer pricing mengalami kenaikan dan penurunan dari tahun 2013 hingga 2019. Pada tahun 2013 nilai rata-rata transfer pricing sebesar 0,387 memiliki rata-rata tax avoidance sebesar 0,272. Pada tahun 2014 nilai ratarata transfer pricing mengalami kenaikan menjadi 0,470 sementara tax avoidance mengalami penurunan menjadi 0,261. Pada tahun 2015 nilai rata-rata transfer pricing mengalami penurunan menjadi 0,440 dengan nilai tax avoidance yang juga menurun menjadi 0,146. Pada tahun 2016 nilai rata-rata transfer pricing mengalami kenaikan menjadi 0,513 yang diikuti dengan kenaikan nilai rata-rata tax avoidance yang sangat signifikan menjadi 0,349. Selanjutnya pada tahun 2017 nilai rata-rata transfer pricing mengalami penurunan menjadi 0,446 dengan nilai rata-rata tax avoidance yang juga ikut menurun menjadi 0,251. Terjadi penurunan kembali terhadap nilai rata-rata transfer pricing pada tahun 2018 sehingga menjadi sebesar 0,414 namun ternyata nilai rata-rata tax avoidance mengalami kenaikan yang sangat signifikan menjadi 0,548. Pada tahun 2019, nilai rata-rata transfer pricing mengalami kenaikan sebesar 0,038 menjadi 0,452 dengan nilai rata-rata tax avoidance yang malah menurun sangat signifikan menjadi 0,063. Hal ini menunjukkan bahwa peningkatan ataupun penurunan terhadap nilai transfer pricing tidak mempengaruhi perubahan terhadap nilai tax avoidance.

Standar akuntansi yang berlaku di Indonesia tidak mengatur dengan rinci mengenai hal-hal yang berkaitan dengan hubungan pihak relasi khususnya mengenai transaksi transfer pricing. Pernyataan Standar Akuntansi Keuangan (PSAK) 7 tentang pengungkapan pihak-pihak relasi hanya mensyaratkan pengungkapan yang terkait dengan hubungan, transaksi, komitmen dan saldo pihak relasi. Hal-hal seperti cara 
mengungkapkan, keterangan transaksi serta metode transaksi yang dilakukan dengan pihak relasi bukan merupakan suatu kewajiban untuk diungkapkan menurut PSAK 7. Dengan demikian, penilaian terhadap transfer pricing dapat menjadi bias dikarenakan adanya perbedaan cara pengungkapan antara satu perusahaan dengan perusahaan lainnya. Selain itu, kelengkapan informasi mengenai pengungkapan transaksi dengan pihak relasi kini menjadi perhatian bagi otoritas pajak di Indonesia yang dibuktikan dengan ditebitkannya Peraturan Menteri Keuangan Nomor 213/PMK.03/2016 tentang Jenis Dokumen dan/atau Informasi Tambahan yang Wajib Disimpan oleh Wajib Pajak yang Melakukan Transaksi dengan Para Pihak yang Mempunyai Hubungan Istimewa dan Tata Cara Pengelolaannya. Namun, informasi ini hanya tersedia bagi otoritas pajak dan bukan merupakan informasi yang bisa dilihat oleh publik yang bisa dimanfaatkan oleh pihak lain untuk menilai kecendrungan suatu perusahaan untuk melakukan praktik transfer pricing. Selain itu, perusahaan yang menjadi sampel dalam penelitian ini lebih banyak melakukan transaksi domestik dibandingkan transaksi dengan pihak relasi di luar negeri sehingga praktik transfer pricing tidak akan memberikan insentif perpajakan dengan asumsi tidak ada perbedaan tarif yang dikenakan terhadap pihak-pihak relasi.

Hasil penelitian ini sejalan dengan penelitian yang telah dilakukan oleh Falbo dan Firmansyah (2018) dan Panjalusman et al (2018) yang menyatakan bahwa transfer pricing tidak berpengaruh terhadap tax avoidance.

\subsection{Pengaruh Return on Asset Terhadap Tax Avoidance}

Profitabilitas merupakan indikator kinerja manajemen dalam mengelola perusahaan untuk menghasilkan laba atau keuntungan. Pada penelitian ini proftabilitas diproksikan dengan Return on Asset (ROA). ROA merupakan suatu indikator yang menggambarkan sejauh mana efektivitas manajemen dalam memanfaatkan seluruh aset yang dimiliki perusahaan. Perusahaan dengan nilai ROA yang tinggi menunjukkan perusahaan tersebut memiliki laba yang tinggi (Kurniasih \& Sari, 2013). Hal ini menunjukkan bahwa manajemen mampu mengelola aset perusahaan secara efektif. Perusahaan yang memiliki ROA negatif menandakan perusahaan tersebut mengalami kerugian yang juga berarti bahwa manajemen kurang mampu untuk mengelola seluruh aset yang ada di perusahaan (Maharani \& Suardana, 2014). Indikator ROA adalah laba bersih setelah pajak dibandingkan dengan total aset yang digunakan oleh perusahaan 
dalam menjalankan operasi perusahaan. Laba yang besar akan meningkatkan beban pajak yang harus dibayar karena laba yang dihasilkan oleh perusahaan merupakan dasar pengenaan pajak sehingga perusahaan akan berusaha untuk menghindari kenaikan jumlah beban pajak dengan melakukan tindakan tax avoidance.

Nilai ROA yang dimiliki oleh sampel dalam penelitian tidak mempengaruhi tax avoidance, baik saat nilai tersebut mengalami peningkatan maupun pada saat nilai tersebut mengalami penurunan. Rata-rata nilai ROA yang dimiliki oleh sampel dalam penelitian ini cukup baik dengan rata-rata nilai ROA tertinggi sebesar 0,098. Nilai ROA menunjukkan bahwa perusahaan sampel telah memanfaatkan asetnya secara efektif untuk mendapatkan laba dari penggunaan seluruh asetnya. Perusahaan yang mampu menghasilkan laba berarti mampu untuk mengatur pendapatan dan pembayaran pajaknya sehingga dalam hal ini perusahaan akan lebih memilih membayar beban pajak daripada harus melakukan tindakan penghindaran pajak. Hal ini dikarenakan untuk melakukan praktik tax avoidance juga akan dibutuhkan biaya-biaya lain yang harus dikeluarkan seperti biaya konsultasi pajak untuk melakukan tax avoidance tersebut, kehilangan reputasi, ancaman hukum maupun denda yang dibayarkan kepada otoritas pajak. Biayabiaya yang harus ditanggung dalam melakukan praktik tax avoidance tersebut harus dipertimbangkan. Sebisa mungkin biaya yang dikeluarkan perusahaan dalam mengimplementasikan praktik tax avoidance seharusnya tidak lebih besar dari manfaat yang akan didapatkan oleh perusahaan. Cost and benefit dari praktik tax avoidance tersebut harus dipertimbangkan agar laba yang didapatkan perusahaan tidak semakin berkurang dikarenakan praktik ini.

Nilai rata-rata profitabilitas yang diukur dengan rasio return on asset mengalami kenaikan dan penurunan dari tahun 2013 hingga 2019. Pada tahun 2013 rata-rata ROA sebesar 0,074 memiliki nilai rata-rata tax avoidance sebesar 0,272, sedangkan pada tahun 2014 rata-rata ROA meningkat menjadi 0,098 dengan nilai rata-rata tax avoidance yang menurun menjadi sebesar 0,261 . Tahun 2015, rata-rata ROA menurun menjadi 0,035 dengan nilai rata-rata tax avoidance yang juga ikut menurun menjadi sebesar 0,146 . Namun, pada tahun 2016 terjadi kenaikan yang tidak signifikan pada nilai rata-rata ROA menjadi sebesar 0,062 yang diikuti dengan nilai tax avoidance yang juga meningkat namun sangat signifikan menjadi sebesar 0,349. Pada tahun 2017, nilai rata-rata ROA mengalami peningkatan sebesar 0,002 sehingga menjadi sebesar 0,064 namun ternyata 
nilai tax avoidance malah mengalami penurunan yang cukup signifikan menjadi sebesar 0,251. Pada tahun 2018, nilai rata-rata ROA kembali menurun menjadi 0,028 dengan peningkatan terhadap nilai rata-rata tax avoidance yang malah meningkat sangat signifikan menjadi 0,548. Pada tahun 2019, kembali nilai rata-rata ROA menurun menjadi sebesar 0,015 dengan nilai tax avoidance yang malah ikut menurun dengan sangat signifikan menjadi 0,063. Hal ini menunjukkan bahwa peningkatan ataupun penurunan terhadap nilai ROA tidak mempengaruhi perubahan terhadap nilai tax avoidance.

Hasil penelitian ini sejalan dengan penelitian yang telah dilakukan oleh Cahyono et al (2016), Nursari et al (2017) dan Permata et al (2018) yang menyatakan bahwa return on asset tidak berpengaruh terhadap tax avoidance.

\section{SIMPULAN, IMPLIKASI DAN BATASAN PENELITIAN}

\subsection{Simpulan}

Penelitian ini dilakukan untuk menguji pengaruh transfer pricing dan return on asset terhadap tax avoidance. Hasil penelitian menunjukkan bahwa transfer pricing tidak berpengaruh terhadap tax avoidance pada perusahaan perkebunan yang terdaftar di BEI. Hal ini dikarenakan tata cara pengungkapan transaksi pihak relasi secara detail belum ditetapkan di dalam PSAK 7 sehingga penilaian terhadap transfer pricing dapat menjadi bias antara satu perusahaan dengan perusahaan lain. Selain itu, perusahaan perkebunan yang menjadi sampel dalam penelitian ini lebih banyak melakukan transaksi domestik dibandingkan transaksi dengan pihak relasi di luar negeri sehingga praktik transfer pricing tidak akan memberikan insentif perpajakan dengan asumsi tidak ada perbedaan tarif yang dikenakan terhadap pihak-pihak relasi. Rasio profitabilitas yang diproksikan dengan return on asset tidak berpengaruh terhadap tax avoidance pada perusahaan perkebunan yang terdaftar di BEI. Keputusan perusahaan dalam melakukan praktik tax avoidance bukan bergantung pada tinggi atau rendahnya laba yang dihasilkan oleh perusahaan melainkan perusahaan harus mempertimbangkan cost and benefit dari praktik tax avoidance tersebut karena dibutuhkan biaya yang besar untuk melakukan tax avoidance.

\subsection{Implikasi}

Adanya penelitian ini menghasilkan kesimpulan mengenai bagaimana pengaruh transfer pricing dan profitabilitas terhadap tax avoidance pada perusahaan perkebunan di 
BEI yang diharapkan akan menambah wawasan dan dapat memberikan inspirasi bagi peneliti selanjutnya untuk melakukan penelitian mengenai faktor-faktor yang mempengaruhi penghindaran pajak dapat mengembangkan teori serta dapat dijadikan sebagai tambahan pengetahuan dan pengembangan teori yang berkaitan dengan tax avoidance.

\subsection{Batasan Penelitian}

Penelitian ini memiliki keterbatasan-keterbatasan yang apabila diatasi oleh penelitian selanjutnya, maka akan dapat memperbaiki hasil dari penelitian ini. Beberapa keterbatasan tersebut adalah :

1. Penelitian ini hanya menggunakan sampel perusahaan-perusahaan yang bergerak dalam sektor perkebunan sehingga hasil penelitian ini tidak dapat digeneralisasikan untuk kelompok industri lain.

2. Periode penelitian yang digunakan dari $2013-2019$.

3. Jumlah variabel yang digunakan dalam penelitian ini masih sangat sedikit sehingga hal ini mungkin akan mempengaruhi hasil analisis penelitian ini.

4. Selain menggunakan Cash Effective Tax Rate (CETR), masih ada jenis alat ukur lain yang dapat digunakan untuk menghitung nilai tax avoidance seperti, Effective Tax Rate (ETR) dan Book Tax Gap.

\section{DAFTAR PUSTAKA}

Annisa, A., Taufik, T., \& Hanif, R. A. (2017). Pengaruh Return on Asset, Leverage, Ukuran Perusahaan dan Koneksi Politik Terhadap Penghindaran Pajak (Studi Empiris Pada Perusahaan Manufaktur yang Terdaftar di BEI Periode Tahun 20122015). Doctoral Dissertation, Riau University.

Arianandini, P. W., \& Ramantha, I. W. (2018). Pengaruh Profitabilitas, Leverage, dan Kepemilikan Institusional Pada Tax Avoidance. E-Jurnal Akuntansi Universitas Udayana. Vol. 22, No. 3. Hal. 2088-2116.

Bahri, A., Darmayanti, Y., \& Ethika. (2015). Pengaruh Karakter Eksekutif dan Corporate Governance Terhadap Penghindaran Pajak Pada Perusahaan Manufaktur yang Terdaftar di Bursa Efek Indonesia (BEI) Periode 2010-2014. Skripsi, Universitas Bung Hatta.

Cahyono, D. D., Andini, R., \& Raharjo, K. (2016). Pengaruh Komite Audit, Kepemilikan Institusional, Dewan Komisaris, Ukuran Perusahaan (Size), Leverage (DER) dan Profitabilitas (ROA) Terhadap Tindakan Penghindaran Pajak (Tax Avoidance) Pada Perusahaan Perbankan yang Listing BEI Periode Tahun 2011 - 2013. 
Journal Of Accounting. Vol. 2, No.2.

Citra, V. T., \& Harto, P. (2019). Transfer Pricing Aggressiveness, Firm Size, Profitability and Tax Haven Utilization As Determinants of Tax Avoidance Empirical Evidence From Companies Listed in Indonesia. Doctoral dissertation, Fakultas Ekonomika dan Bisnis.

Darmawan, I. G. H., \& Sukartha, I. M. (2014). Pengaruh Penerapan Corporate Governance, Leverage, Return On Assets, dan Ukuran Perusahaan Pada Penghindaran Pajak. E-Jurnal Akuntansi Universitas Udayana. Vol. 9, No. 1. Hal. 143-161.

Desai, M. A., Foley, C. F., \& Hines Jr, J. R. (2006). The Demand for Tax Haven Operations. Journal of Public economics, Vol. 9, No. 3. Hal. 513-531.

Falbo, T. D., \& Firmansyah, A. (2018). Thin Capitalization, Transfer Pricing Aggresiveness, Penghindaran Pajak. Indonesian Journal of Accounting and Governance, 2(1), 1-28.

Forum For Corporate Governance In Indonesia (FCGI). (2006). Peranan Dewan Komisaris dan Komite Audit Dalam Pelaksanaan Corporate Governance (Tata Kelola Perusahaan). Seri Tata Kelola Perusahaan (Corporate Governnace), Jilid II. http://www.FCGI.or.id (diakses 21 Januari 2020, 14:15)

Garrison, R. H., Noreen, E. W., Brewer, P. C., Chesley, G. R., Carroll, R. F., \& Webb, A. (2009). Managerial Accounting, Eighth Canadian Edition.

Hanafi, H., \& Harto, P. (2014). Analisis Pengaruh Kompensasi Eksekutif, Kepemilikan Saham Eksekutif dan Preferensi Risiko Eksekutif Terhadap Penghindaran Pajak Perusahaan. Diponegoro Journal Of Accounting. Vol. 3, No. 2. Hal. 1-11.

Hansen, D., Mowen, M., \& Guan, L. (2007). Cost management: accounting and control. Cengage Learning.

Hartoto, R. I. (2018). Pengaruh Financial Distress, Corporate Governance dan Konservatisme Akuntansi Terhadap Tax Avoidance (Studi Empiris Pada Perusahaan Perbankan yang Listing di BEI Tahun 2015-2017). Jurnal Fakultas Ekonomi Universitas Islam Indonesia Yogyakarta. Vol. 10, No. 2. Hal. 1-15.

Heryuliani, N. (2015). Pengaruh Karakteristik Perusahaan dan Kepemilikan Keluarga Terhadap Penghindaran Pajak. Skripsi. Universitas Islam Syarif Hidayatullah. Jakarta. Vol. 9, No. 12.

Hutagalung, H. N. Y. (2017). Pengaruh Good Corporate Governance (Kepemilikan Institusional, Komite Audit dan Dewan Direksi) Terhadap Penghindaran Pajak Pada Perusahaan Industri Manufaktur yang Terdaftar di Bursa Efek Indonesia.

Irawan, H. P., \& Farahmita, A. (2012). Pengaruh Kompensasi Manajemen dan Corporate Governance Terhadap Manajemen Pajak Perusahaan. Skripsi, Depok: Universitas Indonesia. 
Jafri, H. E., \& Mustikasari, E. (2018). Pengaruh Perencaan Pajak, Tunnneling Incentive dan Aset Tidak Berwujud Terhadap Perilaku Transfer Pricing Pada Perusahaan Manufaktur yang Memiliki Hubungan Istimewa yang Terdaftar di Bursa Efek Indonesia Periode 2014-2016. Berkala Akuntansi dan Keuangan Indonesia. Vol. 3, No. 2. Hal. 63-77.

Kaplan, R. S., \& Atkinson, A. A. (1998). Advanced Management Accounting, 3 PrenticeHall. USA.

Kasmir, (2014). Analisis Laporan Keuangan, Edisi Pertama, Cetakan Ketujuh. Jakarta: PT. Rajagrafindo Persada.

Kurniasih, T., \& Sari, M. M. R. (2013). Pengaruh Return On Assets, Leverage, Corporate Governance, Ukuran Perusahaan dan Kompensasi Rugi Fiskal Pada Tax Avoidance. Buletin Studi Ekonomi. Vol. 18, No. 1.

Lingga, I. S. (2012). Aspek Perpajakan Dalam Transfer Pricing dan Problematika Praktik Penghindaran Pajak (Tax Avoidance). Jurnal Zenit. Vol.1, No. 3. Hal. 210-221.

Lutfia, A., \& Pratomo, D. (2018). Pengaruh Transfer Pricing, Kepemilikan Institusional dan Komisaris Independen Terhadap Tax Avoidance (Studi Pada Perusahaan Manufaktur yang Terdaftar di Bursa Efek Indonesia Tahun 2012 - 2016). EProceeding of Management. Vol. 5, No.2. Hal 2386.

Maharani, I. G. A. C., \& Suardana, K. A. (2014). Pengaruh Corporate Governance, Profitabilitas dan Karakteristik Eksekutif Pada Tax Avoidance Perusahaan Manufaktur. E-jurnal Akuntansi Universitas Udayana. Vol. 9, No. 2. Hal. 525539.

Mangoting, Y. (2000). Aspek Perpajakan Dalam Praktek Transfer Pricing. Jurnal Akuntansi dan Keuangan,. Vol. 2, No. 1. Hal. 69-82.

Margaretha, M., \& Jenni, J. (2019). Pengaruh Profitabilitas, Sales Growth dan Leverage Terhadap Tax Avoidance (Studi Empiris Pada Perusahaan Sub Sektor Farmasi yang Terdaftar di Bursa Efek Indonesia Periode 2013-2017). Doctoral dissertation, Universitas Buddhi Dharma.

Napitupulu, I. H., Situngkir, A., \& Edelia, A. (2019). Triggers of Tax Avoidance Practices in Indonesia. International Journal of Economics, Business and Management Research. Vol. 3, No. 11.

Noor, R. M., \& Sabli, M. (2012). Tax Planning and Corporate Governance. in International Conference on Business and Economic Research (3rd ICBER) Proceeding.

Nugraha, R., \& Kristanto, A.B. (2019). Faktor-Faktor yang Mempengaruhi Pemanfaatan Tax Haven. Jurnal Ilmiah Akuntansi dan Humanika. Vol. 9 No. 2.

Nurhayati, I. D. (2013). Evaluasi Atas Perlakuan Perpajakan Terhadap Transaksi Transfer Pricing Pada Perusahaan Multinasional di Indonesia. Jurnal Manajemen dan Akuntansi. Vol. 2, No. 1. 
Nursari, M., Diamonalisa, \& Sukarmanto, E. (2017). Pengaruh Profitabilitas, Leverage, dan Kepemilikan Institusional Terhadap Tax Avoidance. Prosiding Akuntansi. Vol. 3, No. 2.

Olivia, D., Sudarajat, M. A., \& Amah, N. (2019). Pengaruh Leverage dan Profitabilitas Terhadap Tax Avoidance dengan Pengungkapan Corporate Social Responsibility Sebagai Variabel Pemoderasi Pada Perusahaan Subsektor Pertambangan Batubara yang Listing di BEI Tahun 2013-2017. Seminar Inovasi Manajemen, Bisnis Dan Akuntansi I.

Panjalusman, P.A., Nugraha, E., \& Setiawan, A. (2018). Pengaruh Transfer Pricing Terhadap Penghindaran Pajak. Jurnal Pendidikan Akuntansi dan Keuangan. Vol. 6, No. 2. Hal 105-114.

Permata, A. D., Nurlaela, S., \& Masitoh, E. (2018). Pengaruh Size, Age, Profitability, Leverage dan Sales Growth Terhadap Tax Avoidance. Jurnal Akuntansi dan Pajak. Vol. 19, No. 1. Hal. 10-20.

Pohan, C. A. (2013). Manajemen Perpajakan Strategi Perencanaan Pajak dan Bisnis. Jakarta: Gramedia Pustaka Utama.

Praditasari, N. K. A., \& Setiawan, P. E. (2017). Pengaruh Good Corporate Governance, Ukuran Perusahaan, Leverage dan Profitabilitas Pada Tax Avoidance. E-Jurnal Akuntansi Universitas Udayana. Vol. 19, No. 2. Hal. 1229-1258.

Prakosa, K. B. (2014). Pengaruh Profitabilitas, Kepemilikan Keluarga, dan Corporate Governance terhadap Penghindaran Pajak di Indonesia. Simposium Nasional Akuntansi XVII. Mataram.

Rozak, T. S., Hardiyanto, A.T., \& Fadilah, H. (2017). Pengaruh Profitabilitas, Likuiditas, dan Leverage Terhadap Tax Avoidance (Studi Empiris Pada Perusahan Manufaktur Sektor Aneka Industri yang Terdaftar di Bursa Efek Indonesia Periode 2013-2017).

Sartono, A. (2010). Manajemen Keuangan Teori dan Aplikasi. Edisi 4. BPFE Yogyakarta.

Sentanu, A. I., \& Juliani, B. I. H. (2016). Analisis Yuridis Terhadap Transfer Pricing Sebagai Upaya Tax Avoidance (Penghindaran Pajak). Diponegoro Law Journal. Vol. 5, No. 2. Hal. 1-15.

Setiawan, Hadi. (2014). Transfer Pricing dan Risikonya Terhadap Penerimaan Negara. Availablehttps://www.kemenkeu.go.id/sites/default/files/2014_kajian_pprf_trans fer\%20pricing\%20dan\%20risikonya $\% 20$ terhadap $\% 20$ penerimaan $\% 20$ negara.pdf (diakses 20 Januari 2020, 13:12)

Sikka, P., \& Willmott, H. (2010). The Dark Side of Transfer Pricing: Its Role In Tax Avoidance And Wealth Retentiveness. Critical Perspectives on Accounting. Vol. 21, No. 4. Hal. 342-356.

Subagiastra, K., Arizona, I. P. E., \& Mahaputra, I. N. K. A. (2016). Pengaruh Profitabilitas, Kepemilikan Keluarga, dan Good Corporate Governance Terhadap 
Penghindaran Pajak (Studi Pada Perusahaan Manufaktur di Bursa Efek Indonesia. Jurnal Ilmiah Akuntansi. Vol. 1, No. 2. Hal. 167-193.

Subramanyam, K.R., \& Wild, J.J. (2009). Analisis Laporan Keuangan Edisi Kesepuluh. Mc Graw Hill.

Sugiharto, Denny. (2014). Prahara Pajak Raja Otomotif. Available : https://investigasi.tempo.co/toyota (diakses 15 Desember 2019, 20:04)

Suryana, A. B. (2012). Menangkal Kecurangan Transfer Pricing. Available : http://www.pajak.go.id/node/4049?lang=en. (diakses 29 Desember 2019, 11:08)

Syuhada, A., Yusnaini, Y., \& Meirawati, E. (2019). Pengaruh Good Corporate Governance Dan Profitabilitas Terhadap Tax Avoidance Pada Sektor Pertambangan. Jurnal Penelitian dan Pengembangan Akuntansi. Vol. 13, No. 2.

Taylor, G., \& Richardson, G. (2012). International Corporate Tax Avoidance Practices: Evidence from Australian Firms. The International Journal of Accounting. Vol 47. Hal 469-496.

Ulfa, T. N. M. (2015). Pengaruh Profitabilitas, Mekanisme Good Corporate Governance dan Pengungkapan Corporate Social Responsibility Terhadap Tindakan Pajak Agresif (Studi Pada Perusahaan Pertambangan yang Terdaftar di Bursa Efek Indonesia periode 2010-2014). Universitas Muhammadiyah Yogyakarta. Skripsi. 